\title{
The Effect of Ownership Structure, Board Size and Firm Value on Corporate Financial Leverage and Dividends Policy: An Applied Study
}

\author{
Nevine Sobhy Abdel Megeid \\ Associate Professor - Accounting Department \\ College of Management and Technology \\ Arab Academy for Science, Technology and Maritime Transport \\ Nevinesobhy2@hotmail.com
}

\begin{abstract}
The paper aims to investigate the empirical linkage between the explanatory variables, ownership structure and one of the corporate governance mechanism namely board size and firm value on the most important corporate financial decisions - financial leverage and dividend policy in an emerging market, Egypt.

To achieve the research objectives, we used a sample of 50 non-financial firms chosen from the more actively traded listed Egyptian firms on the Egyptian Stock Exchange (EGX) from 2015 to 2020. Measure of corporate financial leverage employed is the total debt/assets ratio. The measures of ownership structure include managerial ownership, institutional ownership, block holder's ownership and foreign ownership. The firm value is computed by contrasting the market value of equity (capital) with the adjusted value of equity. Similarly, the effect of some control variables like firm size, profitability and Tobin's Q has been also examined. The multiple regression models (OLS) were used to analyze the data and to test the research hypotheses using the published annual financial reports and other related data.

Results show for the first hypothesis tested, that managerial ownership and block holder ownership are significantly positively related to corporate leverage, while institutional ownership and foreign ownership are significantly negatively related to corporate leverage, whereas board size is found to be insignificantly negatively correlated and firm value is positively correlated with financial leverage. Firm size used as a control variable is found to be significantly positively correlated with financial leverage, while profitability (ROA) is found to be negatively correlated. For the second hypothesis tested, results show that managerial ownership and foreign ownership are significantly positively related to corporate dividend policy, while block holder ownership and institutional ownership are negatively related to corporate dividend policy. Board size, firm value, all control variables (firm size, Tobin's Q and ROA) are found to be significantly positively correlated with dividend yield.

The empirical findings suggest that board size and ownership structure playing an important role and influence their power in deciding the Egyptian corporate financial decisions regarding the financial leverage and dividend decisions.

Keywords: Ownership Structure; Board Size; Firm Value; Financial Leverage; Dividends Policy; Egypt.
\end{abstract}




\section{Introduction}

Company policies are influenced by the ownership structure. The importance of majority shareholders influences decisions in their favor, such as capital structure and dividend decisions. The relationship between ownership structure, dividend structure, and company financial leverage has been an important area of corporate governance research for many years. To ensure best performance and reduce agency costs, the ownership structure is among other factors such as board of directors, leverage, motivational payments, dividends and insurance benefits.

Dividend policy has long been a source of argument in business literature and research. It has an impact on share prices and, as a result, firm value, which is directly related to shareholder share value. Furthermore, it serves as the foundation for the corporate sector's monetary economic stability. This policy is still difficult to define across many business organizations within the same country or across borders. The distinctions are attributed to differences in business production, economics, and financial goals in terms of investment and shareholders. The distribution of shares among shareholders has a great impact on corporate behavior that relies on shareholder voting. According to (Gugler 2003), the majority vote gives major shareholders considerable power and discretion in making important decisions such as dividend decisions and dividend rates. Farinha (2003) argues that dividends play a role in managing public company issues by facilitating a major oversight of the company's activities and performance by the capital markets.

Debt policy is the determination of the amount of debt used to manage and run the firm's operations using the debt to equity ratio, which can be computed by dividing the firm's total liabilities by its own capital. The firm's management should consider the loan amount in light of the other parties who have an interest in the firm's ability to pay the interest and loan principal (Handriani and Robiyanto 2019).

Dividends are paid out of net profit or profit after tax (earnings after taxes) to shareholders. The dividend decision is concerned with the amount of the balance between retained earnings and dividends. Because of the behavior of shareholders who prefer dividends, but also those who expect growth by reinvesting retained earnings in the company, this decision must be made as optimally as feasible. If the corporation decides not to pay dividends, investors' returns on shares will be lower (Purbawangsa and Rahyuda 2020). 
Dividend policy refers to the stability and growth of dividends. When dividends are paid, all interest is deducted from reserves; otherwise, all retained earnings are deducted from reserves. Dividend policy is thus a source of contention between management and shareholders. Companies grow and develop, and then profit or lose money over time. This profit is made up of retained earnings, and profits are distributed. Retained earnings are one of the most important funding sources for financing the company's growth in the next phase (Tamrin et al. 2018).

Agency theory suggests that outside shareholders prefer dividends to retained earnings because insiders can abuse the company's tax withholding cash. This dividend preference can be even stronger in emerging markets where investor protection is inadequate. Silva et al. (2004) describes one of the most important and controversial corporate governance issues related to the structure of share ownership in the context of improving a company's performance. Companies can also be exposed to financial pressure, which is also heavily influenced by the company's ownership structure. Factors that influence the determination of market efficiency can provide information on two aspects. One is diversification of shareholder risk, and the other is information on possible agency problems in corporate management. In this study, researchers consider two ownership structures, such as institutional ownership and administrator ownership. The property of an institutional investor is that of another institution or entity that is usually of substantial value and can be accountable and managed by the management of the company in order to make reasonable decisions that please its shareholders. It is a property. Several previous studies on institutional ownership were conducted by Dewi (2008), Jayanti and Puspitasari (2017), and Djumahir (2011), found that there is a negative relationship between institutional ownership in the payment of dividends, while other studies found different results as those conducted by Arifin and Asyik (2015) and Hommei (2011), they found that institutional ownership has a positive impact on dividend policy.

According to Jensen and Meckling (1976), the agency problem arises when the proportion of institutional ownership of firm stock is less than 100 percent, causing managers to become selfish and the implementation to be based on maximizing corporate value in making an investment decision. At a very high level of ownership, institutional investors have a tendency to impose policies that are not optimal, regardless of the interests of minority shareholders, who have voting power (Handriani and Robiyanto 2019). 
Managerial ownership is one facet of corporate governance that can minimize agency costs if the percentage of the firm's ownership structure is increased, allowing a manager to participate in stock ownership that tries to align the manager's interests with those of the shareholders (Asiri et al. 2018).

Dividends are likely to play a smaller role in addressing agency costs in the presence of alternative monitoring mechanisms such as large institutional block holders.

Institutions may, nevertheless, be able to influence a company's dividend payouts in order to improve managerial supervision through external capital markets, particularly if they consider their own direct monitoring efforts are insufficient or too costly.

Managerial share ownership aligns managers' and shareholders' interests, as managers are less inclined to participate in actions that are not in shareholders' best interests (Abdelsalam and Elsegini 2008).

The dividend policy determines whether the profits generated by the company are distributed to shareholders as dividends or held in the form of retained earnings for future investment financing. If a company decides to distribute profits as dividends, retained earnings will decrease and the total of internal or internal sources of funding will decrease further. If the company is profitable at this point, but only a small profit, it is not profitable at all. Therefore, the company does not have to pay or distribute dividends in the form of cash or stock (Abrar and Arisandi 2019). According to the dividend residual theory, if a company withholds profits, these can be used to fund the operational activities of a company that is expanding and investing in many types of assets (Gitman and Zutter 2012). This opportunity for investors to analyze all factors related to the decision-making of the company's management in order to distribute dividends to investors.

The conflict of interest that will result in agency costs can be minimized with supervision that aligns both parties' interests. According to Weston and Copeland (2002), one of the advantages of dividend payments is that they can minimize agency expenses between the company's manager and owner, hence reducing the conflicts of interest between the two parties. As a result, a proper dividend strategy is required to meet investor dividend expectations while still allowing the company to thrive (Asiri et al. 2018). 


\section{Research Problem}

Dividend policy and financial leverage decisions are two important areas of research in corporate finance, as both decisions are an integral part of corporate policy. Shareholders generally believe that dividends are an influential signal of a company's ability to grow profits. An important area of research in emerging markets is now the impact of corporate governance on dividend policy, as investors place greater emphasis on dividend policy options in capital markets.

Dividend policy is an important area of research in corporate finance because dividend policy decisions are a major component of corporate policy. Dividends, in general, are viewed as an influential signal by shareholders regarding a company's ability to increase earnings. Currently, an important area of research in emerging markets is examining the impact of corporate governance on dividend policy, as investors give more weightage to dividend policy options in the capital markets. As a result, researchers acknowledged that some emerging markets offer opportunities for further research, as emerging markets now play a significant role in international financial activity.

The dividend policy determines whether the profits generated by the company are distributed to shareholders as dividends or held in the form of retained earnings for future investment financing. If a company decides to distribute profits as dividends, retained earnings will decrease and the total of internal or internal sources of funding will decrease further. If the company is profitable at this point, but only a small profit, it is not profitable at all. Therefore, the company does not have to pay or distribute dividends in the form of cash or stock (Abrar and Arisandi 2019). According to the dividend residual theory, if a company withholds profits, these can be used to fund the operational activities of a company that is expanding and investing in many types of assets (Gitman and Zutter 2012). This opportunity for investors to analyze all factors related to the decision-making of the company's management in order to distribute dividends to investors. 


\section{Research Aims and Questions}

\section{The primary two fold aims of this research are as follows:}

- To investigate the effect of ownership structure, board size and firm value on financial leverage.

- To determine the effect of ownership structure, board size and firm value on dividend policy.

This research contributes to existing literature and fills existing gaps in the literature by demonstrating the relationship between the financial leverage of Egyptian companies and the size, ownership structure and corporate value of the board in dividend policy. The size of the board of directors is considered one of the most important tools of internal governance practices, so the effectiveness of the board of directors may vary depending on the characteristics of the members of the board. It also introduces the importance of ownership structure and corporate value, and their impact on a company's financial debt (capital structure) and dividend policy. Therefore, this research may benefit business owners, investors, policy makers, and other stakeholders.

The findings could answer the following two major research questions:

1. What are the effects of ownership structure, board size and firm value on financial leverage?

2. What are the effects of ownership structure, board size and firm value on dividend policy?

\section{Literature Review and Hypotheses Development}

\subsection{Ownership Structure and Financial Leverage}

Bansal (2005) points out that the investor and shareholder (owner) communities are generally made up of individuals, groups and institutions, and their interests, goals, investment duration and skills can vary widely. As a general shareholder, you have the right and ability to influence the basic issues of the company, such as the appointment of directors, changes to the company's organic documents, approval of extraordinary transactions, changes to the company's internal status, and the appointment of auditors.

Jensen and Meckling (1976) divide ownership structure into two categories based on capital contributions: inner investors (managers) and 
outside investors (debt holder and equity holder). Ownership structure is defined by Abel and Okafor (2010) as the percentage of shares held by managers (managerial ownership), institutions (institutional ownership), the government (state ownership), foreign investors (foreign ownership), families (family ownership), and so on (Soewarno et al. 2017).

Management ownership is the percentage of share ownership owned by management that actively participates in committee and board decisions. Management involvement in stock ownership can reduce brokerage costs. Brokerage costs are incurred due to the different interests of shareholders and management. The cost of reducing disputes leads to the cost of an agency for shareholders to oversee the behavior of managers in running the company. As management's participation in the stock increases, management also makes decisions for the benefit of management, not only harming shareholders.

Jensen (1976) points out management's preference to grow the company through overinvestment for private gain. For Jensen, this means that the disciplinary role of debt that constrains managers' opportunistic behavior becomes obsolete. Said (2013) assumes that the choice of lever itself causes agency problems between shareholders and management. Using external capital in a company's capital structure incurs agency costs. In 1976, Jensen and Mechling developed the agency cost theory. This was later defined as an agency relationship. This includes transferring decision-making power to agents.

According to agency theory, the path of professional management style, which is the separation of property and management, is caused by the manager's inadequate workload, indulging in benefits, and the choice of input or output according to his or her taste, can lead to conflicts. For these reasons, a company may not be able to maximize its value. Conversely, for these reasons, you can maximize your wealth and utility. On the other side, the conflict between debtors (creditors) and shareholders is due to moral hazard. Agency theory suggests that information asymmetry and moral hazard are greater for SMEs. Conflicts can arise between shareholders and creditors due to different demands on the company (Soewarno et al. 2017).

A study by Bodaghi and Ahmadpour (2010) shows that ownership of an organization has a positive relationship with its capital structure, which is in line with the philosophy of corporate governance. According to a study conducted in Pakistan by Arshad and Safdar (2009), ownership of business owners has a significant impact on the capital structure, which is expressed as a debt-to-capital ratio. Short, Keasey and Duxbury (2002) also examine the 
impact of ownership structures on the financial structure of UK companies. Their results show that while there was a positive link between management ownership and leverage ratio, a negative link was observed between ownership of large external shareholders and financial leverage. However, they found that the relationship between management ownership and leverage ratio is not important in the presence of large external shareholders.

Another study, conducted in 2002 by Brailsford, discovered that managerial ownership and leverage may be associated in a nonlinear approach. He demonstrates the existence of a negative association between managerial equity holding and gearing levels. He discovers that low levels of management ownership result in low levels of agency conflicts and a higher level of debt.

Management, like other shareholders, suffers asset losses if it invests less than the optimal level of debt for the company's capital structure. Some studies have found that the majority of management's holdings have high debt policies. We have found that companies with higher insider ownership have higher levels of debt and are more likely to engage in activities that maximize shareholder wealth (Abor 2008).

Institutional investors play a significant role in financial markets, and their impact on corporate governance has been highlighted as a result of privatization policies implemented by emerging nations such as Egypt. Institutional investors have extensive experience acquiring and evaluating information regarding firm performance and, as a result, can reduce agency costs (Jensen, 1986; Abobakr and Elgiziry 2016).

The level of ownership controlled by institutional investors such as foundations or investment funds can act as a mechanism to reduce the level of information asymmetry between owners and managers; in other words, when information about the organization is available to all investors, they can make decisions that are aligned with maximizing firm value (Ramirez and Ferrer 2021).

Hussainey and Aljifri (2012) find that there is a negative influence on the debt-to-equity ratio. Firms with a high percentage of shares held by institutional shareholders appear to use less debt financing, supporting the pecking order idea.

In a similar way, Fosberg (2004) studies the issue of regulatory authority and debt financing in US firms. In his empirical research, he studies the correlation between ownership of block holders owning 5\% or more of company stock and debt-to-equity ratio. He found that leverage was positively 
correlated with block holders' share shares, suggesting that block holders exercise effective oversight on the board of directors so that they can control the use of shares and use of debt in a firm's capital structure.

Managerial share ownership has been proposed as a technique for reducing agency conflicts by aligning management and shareholder interests. The precise relationship between managerial share ownership and business debt, on the other hand, is complicated. Furthermore, the literature is inconsistent and ambiguous. According to Jensen and Meckling (1976), managerial share ownership reduces managerial incentives to spend perquisites, expropriate shareholders' money, and participate in other nonmaximizing activity. However, when the percentage of management shares owned increases, control of the firm shifts from external shareholders to the managers, management entrenchment occurs at a certain time. There will be few limitations on managerial behavior at this level, leading to a rise in managerial opportunism. However, because of management's enormous exposure to the firm at high levels of managerial ownership, substantial risk from self-interest occurs. As a result, at high levels of managerial share ownership, there are more incentives to reduce debt than would otherwise be the case (Brailsford et al. 2002).

\section{Therefore, the research suggests the following hypothesis:}

Ownership structure has a significant positive impact on financial leverage.

\subsection{Board Size and Financial Leverage}

Members of the board of directors are one of the most important essential elements of the governance instrument in monitoring and understanding the firm's efficient and appropriate procedures. The board of directors is critical in reducing the firms' disappointment. Firm board members are in charge of managing developments and issuing tactical decisions.

The relevance of the board of directors in decision making is revealed by a survey of the study's literature. The size of the board of directors varies depending on the business legal form (Soewarno et al. 2017).

Previous studies have yielded conflicting results about the relationship between financial leverage and board size. On the one hand, Berger et al. (1997) discovered that board size has a negative impact on financial leverage; on the other hand, Jensen (1986) discovered that companies with larger board sizes have higher financial leverage than companies with slightly smaller 
board sizes and proposes that companies with larger boards are more likely to practice financial obligation rather than equity financing (Tahir et al. 2020).

Jensen (1986) argues that board length is negatively correlated with the board's functionality to advocate and take part in long-time period making plans due to the problems related to organizing and coordinating big numbers of administrators.

Wen et al. (2002) discover a link between board size and leverage ratio. They went on to say that larger boards, which are more entrenched as a result of effective monitoring, seek higher leverage to increase company value. Adams and Mehran (2002) argue that a few companies want big forums for powerful supervision. However, (Sheikha and Wang 2011; Hussainey and Aljifri 2012; Ganiyu and Abiodun 2012) discover that the whole wide variety of board of administrators is the that board length has a superb relation to company debt to fairness ratio and advise that big forums are in all likelihood to exercise powerful tracking because of the enough numbers of administrators which could represent exclusive ordinary our bodies and that practice excessive debt degree to boom the organization value, furthermore, big forums boost conflicts which could cause issue in achieving a consensus in selection making which might also additionally weaken company governance ensuing in better leverage (Abobakr and Elgiziry 2016).

According to the literature, a large board with a large number of members is more valuable than a board with a small number of members because of its extensive information, capital and external relations. The actions of the directors of a company can have a significant impact on the market value of the company. The positive link between board size and financial leverage is the idea that companies with a large number of board members can have more external relationships to improve access to debt finance. It seems to support it.

The board of directors is a corporation's top body in charge of controlling the company and its operations. It is critical in strategic decisions about financial mix. Bodaghi and Ahmadpour (2010) discovered that board size is highly connected to capital structure in their multivariate regression investigation of the association between corporate governance, ownership structure, and capital structure. The data on the direction of the association between board size and capital structure was conflicting.

Moreover, Abor and Biekpe (2007) use multivariate regression model to examine the relationship between corporate governance and capital structure decisions in Ghanaian SMEs. The findings show a negative link between 
board size and leverage ratios. It was determined that SMEs with larger boards have a low level of gearing.

Wen, Rwegasira, and Bilderbeek (2002), on the other hand, discovered a positive link between board size and capital structure. He contends that huge boards implement a policy of increasing levels of gearing to increase business value, particularly when these are established as a result of increased regulatory oversight. Furthermore, he suggested that a larger board may have trouble reaching a decision-making consensus, which can ultimately impact the quality of corporate governance and translate into higher levels of financial leverage. According to Anderson, Mansi, and Reeb (2004), the cost of financing for larger boards is often lower because lenders believe that these companies are being supervised more efficiently by a diverse portfolio of experts.

\section{Therefore, the research suggests the following hypothesis:}

\section{Board size has a significant positive impact on financial leverage.}

\subsection{Firm Value and Financial Leverage}

Leverage must be managed because the use of high debt raises the firm's value. Companies will cover the interest loan, reducing taxable income and providing benefits to shareholders. Leverage is a funding strategy that is closely related to a company's decision to finance itself. Companies that use debt face a very high risk of not repaying the debt, so the use of debt must be carefully monitored in order for the company to be profitable (Mappadang 2021). Laghari (2017) investigates the influence of operating and financial leverage on firm value using panel data from 2005 to 2009 from companies registered on the Karachi stock exchange (KSE) in Pakistan. The regression results showed that the degree of operating leverage (DOL) and degree of financial leverage (DFL) have a significant impact on company value. Operating leverage and financial leverage levels, which are a measure of business risk and financial risk, can have a substantial impact on the company's value.

The firm's efforts to resolve agency conflicts between managers and shareholders through dividend payments may result in a conflict between shareholders or management and the lender. This was due to the fact that boosting dividend payout increases the company's prospects of utilizing external finance. The relationship between financial leverage and dividend policy emerges from creditor's tight loan covenants (including dividend 
payment limits) to safeguard its interests. As a result, the bigger a company's financial leverage, the lower its dividend policy.

Essentially, higher leverage is expected to result in higher firm value because debt is not tax deductible, which increases the firm's net income or future streams of income. However, because this future stream of income must be discounted by the risk-adjusted cost of the fund, the default risk will have a negative impact on the gains in the form of a lower present value of future streams of earnings and, as a result, market value (Ibrahim and Isiaka 2020).

To reduce agency difficulties, financial leverage can be employed as a company monitoring tool. This can boost firm worth because agency issues can be a barrier to increasing firm value (Jensen 1986). Financial leverage, in addition to being a monitoring instrument, can boost corporate value through tax deductibility and signaling. As a result, raising financial leverage at an optimal level will boost firm value (Rizqia and Sumiati 2013).

Therefore, the research suggests the following hypothesis:

Firm value has a significant positive impact on financial leverage.

\subsection{Ownership Structure and Dividend Policy}

Dividend policy is a choice on whether the company's profits will be dispersed to shareholders in the form of dividends or maintained to support future investments (Sartono 2001).

Many scholars have kept a close eye on the relationship between ownership structure and dividend payout. Some of them have even attempted to investigate the agency cost hypothesis from the standpoint of ownership structure.

Individual investors are less effective at monitoring management than institutional investors. Institutional investors have a stronger incentive and capability to collect and assess information about their investments due to the scale of their investments and the resources at their disposal. They also have the clout to discipline management and even force changes when management performs poorly. Because institutions manage a greater pool of funds and invest more money, they should devote more resources to monitoring in order to avoid risk (Tahir et al. 2020).

To eliminate agency costs, institutional owners prefer free cash flow distribution in the form of dividends. Institutional investors provide critical monitoring services; act as a check on managers' opportunistic behavior, and aid in the reduction of agency costs (Shah et al. 2011). 
Several studies disagreed on the function of a manager in ownership. Managers wearing the ownership hat may aid in the removal of the free cash flow problem and may better promote the shared interests of management and shareholders. As a result, the payout ratio is high, allowing the managers to maintain more shares.

The dividend policy is influenced negatively by managerial ownership. In other words, the higher the management share, the higher the dividend paid. High ownership of management balances the interests of management with the interests of shareholders. Management who is also a shareholder also bears all consequences that benefit or harm shareholders, so more cautious management is subject to the company's management policy of increasing shareholder wealth. Investing in a company by a manager usually results in a dividend payment decision that outweighs the return on the investment.

The results of this study are consistent with those by Ullah et al. (2012) who discovers that the ownership of a manager adversely affects the dividend policy. The results of this study are inconsistent with the study by Arifin and Asyik (2015), who found that manager ownership, had a positive impact on dividend policy.

Institutional ownership is the percentage of shares held by an institution at the end of the year. High levels of institutional ownership lead to strict oversight of managers' behavior in pursuit of self-interest. According to Embara et al. in (2012), institutional ownership influences dividend policy, the higher the ownership of the institution, the lower the cost of the agency and the companies tend to pay lower dividends (Asiri et al. 2018).

The impact of institutional ownership on dividend policy is negative. According to the test results, the high proportion of institutions in the Indonesian manufacturing structure has no effect on the distribution amount. Institutional investors have different expectations than individual investors.

Because their investment is generally long-term, companies that reinvest their profits more than companies that distribute most of their profits in dividends so that the percentage of the institution's stock does not affect the amount of dividends the company pays. The results of this study support a previous study by Djumahir (2011), who stated that institutional ownership does not have a significant impact on dividend policy. The direction to test institutional ownership of this aggressive dividend policy supports Arifin and Fun (2015) and Hommei (2011).

Since internal ownership provides a way to use internal funds directly for unprofitable projects, researchers are proposing dividend payments as a tool 
for controlling the managed compass. This approach expects a negative relationship between insider ownership and dividend payments.

Managerial ownership arose as a result of the firm's realization of the agency problem. It minimizes the likelihood of managers acting in an unfavorable and destructive manner to the interests of shareholders. Dividends were not paid as a direct outcome of a closer monitoring procedure to investment management. High dividend payments prevent disputes between managers and shareholders; hence, the higher managerial ownership, the lower corporate dividend policy. Firm attempts to alleviate agency problems by implementing monitoring systems via managerial ownership and dividend programs might indirectly boost firm value (Rizqia and Sumiati 2013). This is because management ownership aligns the interests of managers and shareholders. Managers will strive to raise firm value, which is reflected in the firm's stock price (Jensen 1986). As a result, managerial ownership has the potential to improve business value.

Ullah et al. (2012) investigate the primary elements that determine dividend policy in the context of the agency relationship by using several proxies for ownership structure, such as institutional ownership, managerial ownership, and foreign ownership. Data from 70 KSE-listed enterprises from 2003 to 2010 were used in this investigation. The researchers discover that managerial ownership has a detrimental impact on corporate dividend policy. By contrast, both institutional and foreign ownership have a favorable impact on dividend payouts. These findings are critical because they demonstrate how dividend policy might reduce agency cost.

Abdullah et al. (2012) study the relationship between a firm's ownership structure and its dividend policy. They conclude that concentrated ownership has a positive impact on dividend policy, but managerial ownership has a negative impact on dividend policy. However, there is no evidence of an association between foreign ownership and dividend policy.

Al-Gharaibeh et al. (2013), for example, attempt to study the impact of ownership structure on dividend policy by constructing a sample of listed firms on Jordan's stock exchange from 2005 to 2010. The findings also reveal that managerial ownership has a detrimental impact on dividend payout. Similarly, Thanatawee (2013) investigates the association between ownership structure and dividend policy using data from 1,927 Thai enterprises listed on the stock exchange between 2002 and 2010. The findings show that sample firms are more likely to pay dividends when they have a higher ownership concentration or when the largest shareholder is an institution, and that firms 
pay bigger dividends when the largest shareholder, especially an institution, owns a larger percentage of the stock. Furthermore, he discovered that higher institutional (individual) ownership increases (decreases) the likelihood of paying dividends and the amount of a dividend payout (Shahid et al. 2016).

The company's ownership structure also has an impact on how it strives to enhance its financial performance. This is extremely sensible because the owner has considerable authority to select who will sit in management, who will then set the direction of the company's policies in the future. Many of these businesses have adopted a profit-driven orientation. Companies that can generate significant profits are deemed to be successful or to have high financial performance. It is inversely proportionate if the company's earnings are comparatively modest, it can be claimed that the company is less successful or its performance is poor. Profitability is the final consequence of a lot of policies and actions made by corporate management (Purbawangsa and Rahyuda 2020).

Therefore, the research suggests the following hypothesis: policy.

Ownership structure has a significant positive impact on dividend

\subsection{Board Size and Dividend Policy}

Dividends are the result of improved governance practises. According to this viewpoint, firms with better governance structures may pay higher dividends. However, interpreting whether larger boards reflect better monitoring appears difficult because the results on board size and performance are also mixed. However, the overall agency perspective states that larger boards imply more directors on the board, which reduces coordination among them; thus, firms with large board sizes may pay high dividends, because increased monitoring supports the monitoring hypothesis, increased monitoring by larger boards reduces dividend payout. Furthermore, greater oversight by larger boards reduces the need for dividends as a substitute governance mechanism (La Porta et al. 2000).

The size of the company's board of directors has a big impact on the executives' ability to supervise and control administrators. According to the research, there is a significant positive association between board size and dividend payout policies. Similarly, Uwuigbe (2013) used regression analysis to find a positive relationship between board size and dividend pay-out policy (Tahir et al 2020). 
Furthermore, Subramaniam et al. (2011) found a strong positive correlation between board size and dividend payout policies. Ajanthan (2013) found a correlation between board size and dividend payout, however it was statistically insignificant.

Between 2000 and 2009, Nuhu (2014) investigated the relationship between board size and dividend payout for Ghanaian firms. According to the study's findings, there is a positive and statistically significant relationship between board size and dividend payout. As a result of increased monitoring activity, the larger the board, the higher the level of dividends paid out.

Because board size was the first mechanism researched for corporate governance, there are inconsistent findings in the literature. It's critical to understand how dividend policy works as a buffer in understanding the concept of a larger or smaller board size in contributing to strong corporate governance.

Therefore, the research suggests the following hypothesis:

Large Board size has a significant positive impact on dividend policy.

\subsection{Firm Value and Dividend Policy}

Each company has short and long-term strategic goals in order to achieve shareholder wealth. The short-term goal is for the company to gain the most benefit from the resources it owns, while the long-term goal is to maximize the firm's value. Aside from that, maintaining the firm's sustainability is an important thing that must be done for a company, particularly in terms of the welfare of its owner. The value of the firm is important for stakeholders because if the firm's value is high, the shareholders will benefit (Mappadang 2021).

A company's primary goal is to maximize company value by ensuring the well-being of its investors. Optimizing company value can be interpreted as a strategy used by the company to maximize its value when it enters the market or goes public (Fahmi 2011).The firm's value in this research is computed as the sum of the market values of all existing instruments, which include common stock, preferred stock, and debt.

Dividend policy refers to the decision about how much profit to distribute as dividends and how much to keep as retained earnings. Assume the company decides to distribute the majority of its profits as dividends. In that case, it will reduce retained earnings and, as a result, the internal funding or internal financing with the lowest cost. One of the most important financial 
management functions is determining how much profit to allocate for dividend payments on the one hand and how much profit to retain as retained earnings on the other, as both decisions affect firm value (Mubaraq et al. 2021).

The value of the company is also linked to the total value of money, which corresponds to all types of monetary rights. It is based on constant future predictions about the current value of the future cash flow obtained from assets reduced to the company's weighted regular worth of money. The value would be determined by the dividend streams that stockholders would receive over the course of the organization's existence.

An increase in the value of a company means an increase in the monetary value of its shareholders, as stated by the ratio of the value of the market stock to the book value associated with the stock. Therefore, creating value by a company is not just about making money or profits for the company itself. Rather, it is about maintaining shareholder interest in the company's business policies regarding market conditions and stock prices. By one definition, it is the sum of all assets owned by a company, whether from shareholders or investors (Alenazi and Barbour2019).

When it comes to dividend policy and firm value, dividends per share and dividend yield are both important factors in determining share prices. Dividend per share has a positive significant relationship with firm value, whereas dividend yield has a negative significant relationship with firm value (Soewarno et al. 2017).

Most companies that have committed to paying dividends to shareholders believe that dividend policy has an impact on the value of the firm's stock price. This was due to the fact that dividends reflect a company's future profit prospects.

Dividend policy was expected to send a positive signal about the firm's condition. As a result, dividend policy can boost firm value (Rizqia and Sumiati 2013).

Dividend payment is a strategy used to improve the company's performance. The payment of a cash dividend to shareholders is thought to increase the value of the company. Investor perception is very important to know the financial characteristics since investors will assess whether the company can be trusted to invest money and buy a stock in the capital market, which is the main focus in firm value making decisions by investors to invest in a company or not (Mappadang 2021). Furthermore, the firm's worth is significant to creditors, who are less concerned about making loans to these 
businesses since they can see that they will be repaid and that they will receive a return or yield.

The goal is to increase the company's worth as much as possible. If, on the other hand, the company grinds to a halt, the creditor's right will take precedence, and the value of the company's shares will plummet. Firm value is an economic image that depicts each company's market value (Saifi et al. 2015). It specifies the amount of debt holders' claims, all securities, preferred shareholders' claims, common stockholders' claims, and minority interests' claims. Firm value is one of the most important factors to consider when valuing a company, performing financial modeling, calculating accounting, and performing portfolio analysis. The overall worth of distinct assets, or the company's present value, is equal to the company's value (Brealey et al. 2011). Furthermore, the firm's value is equal to the market value of debt and equity, minus capital, and is identical to the capital of the company (Mubaraq et al. 2021).

Faulkender et al. (2006) concluded that monetary policy decisions are collectively based on the design of capital structures and the definition of dividend policy. As an extreme example, the company uses high leverage and low equity, with most control in the hands of investors. Conversely, if your company uses low leverage and high equity, you need to reduce the dividends paid and put more control in the hands of your manager. Through discussion, the ultimate goal of the company is to increase equity capital or increase investor profits. Therefore, choosing the optimal capital structure and dividend policy, both or individually, can have a positive or negative impact on the value of the company.

Therefore, the research suggests the following hypothesis:

Firm value has a significant positive impact on dividend policy.

\section{Research Conceptual Framework}

In this research, three independent variables - namely ownership structure, board size and firm value - influence the dependent variable, financial leverage proxied by debt/assets ratio and dividend policy proxied by dividend yield ratio. Board size is used order to measure corporate governance practice. The following diagram presents an overview of the research conceptual framework. 


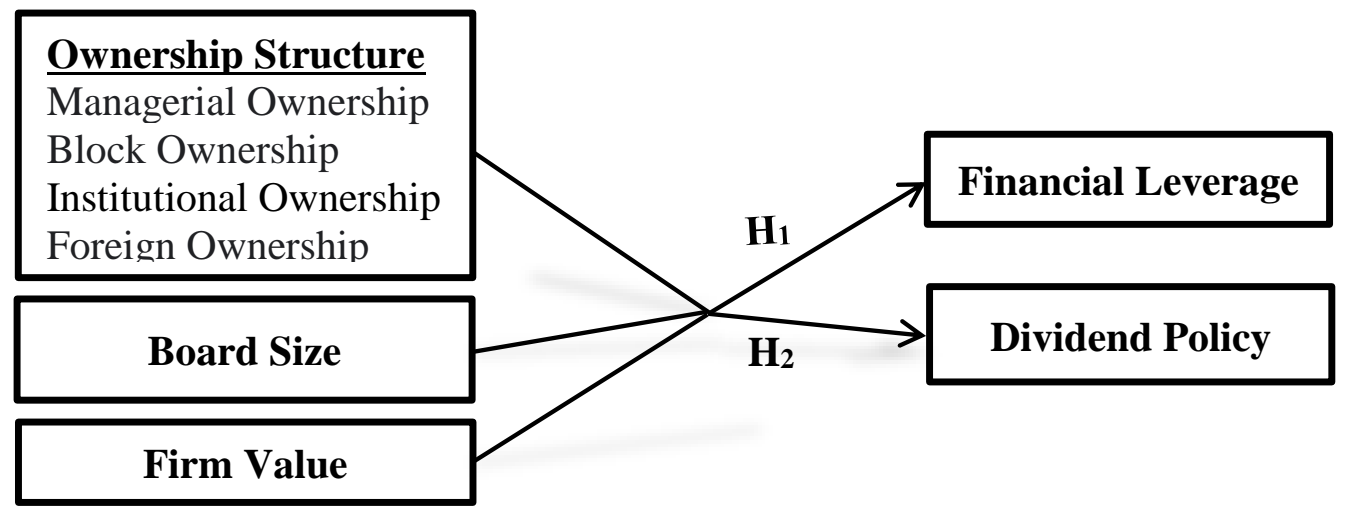

Figure (1): Research Conceptual Framework

\section{Research Methodology}

To investigate the validity of the research hypotheses, the sample used comprises of 50 manufacturing companies listed in the Egyptian Stock Exchange with the observation period of 2015-2020.

The financial data analyzed was obtained from firms' annual reports published by Mubasher Misr. To examine the hypotheses, regression analysis was applied.

\subsection{Research Variables and Regression Model}

For examining the relationship among the research variables, the researcher used the data analysis for both time series and cross sectional data to investigate the statistical impact of ownership structure, board size and firm value on financial leverage and dividend policy using the following two multiple regression models as follows:

First regression model, used to examine the effect of ownership structure, board size and firm value on financial leverage.

$\mathrm{H}_{1}$ : Firm ownership structure, board size and firm value have significant positive impact on financial leverage.

H1 Sub-hypotheses:

- Ownership structure has a significant positive impact on financial leverage.

- Large Board size has a significant positive impact on financial leverage.

- Firm value has a significant positive impact on financial leverage. 


$$
\begin{gathered}
\mathrm{FL}_{\mathrm{it}}=\boldsymbol{\beta}_{0}+\beta_{1} \mathrm{MO}_{\mathrm{it}}+\beta_{2} \mathrm{BO}_{\mathrm{it}}+\beta_{3} \mathrm{IO}_{\mathrm{it}}+\beta_{4} \mathrm{FO}_{\mathrm{it}}+\beta_{5} \mathrm{BS}_{\mathrm{it}}+\beta_{6} \mathrm{FV}_{\mathrm{it}}+\beta_{7} \\
\mathbf{R O A}_{\mathrm{it}}+\beta_{8} \mathrm{FS}_{\mathrm{it}}+\beta_{9} \mathrm{TQ}_{\mathrm{it}}+\varepsilon_{\mathrm{it}}
\end{gathered}
$$

\section{Where:}

Dependent variable $=$ Financial Leverage $(\mathbf{F L})$.

$\boldsymbol{\beta}_{0}=$ denotes the fixed of the regression equation.

$\boldsymbol{\beta}_{1,2}, 3$ and $4=$ MO, BO, IO and FO denotes regression coefficient of managerial ownership, block ownership, institutional ownership and foreign ownership, respectively, that are used as measures for ownership structure (OS).

$\boldsymbol{\beta}_{5}=$ denotes regression coefficient of board size $(\mathbf{B S})$.

$\boldsymbol{\beta}_{6}=$ denotes regression coefficient of firm value (FV).

$\boldsymbol{\beta}_{7,8}$ and $\boldsymbol{\beta}_{9}=$ denotes control variables, regression coefficient of return on assets (ROA), Tobin's Q (TQ) and firm size (FS).

$\mathbf{I}_{\mathbf{t}}=$ Firm $\mathrm{i}$ in period $\mathrm{t}$.

$\mathbf{T}_{\mathbf{i}}=$ Year fixed effect.

$\varepsilon_{\mathrm{it}}=$ Standard error term.

Second regression model, used to examine the effect of ownership structure, board size and firm value on dividend policy.

$\mathrm{H}_{2}$ : Firm ownership structure, board size and firm value have significant positive impact on dividend policy.

$\underline{H}_{2}$ Sub-hypotheses:

- Ownership structure has a significant positive impact on dividend policy.

- Large Board size has a significant positive impact on dividend policy.

- Firm value has a significant positive impact on dividend policy.

$$
\begin{gathered}
\mathrm{DP}_{\mathrm{it}}=\boldsymbol{\beta}_{0}+\boldsymbol{\beta}_{1} \mathrm{MO}_{\mathrm{it}}+\boldsymbol{\beta}_{2} \mathrm{BO}_{\mathrm{it}}+\beta_{3} \mathrm{IO}_{\mathrm{it}}+\beta_{4} \mathrm{FO}_{\mathrm{it}}+\beta_{5} \mathrm{BS}_{\mathrm{it}}+\beta_{6} \mathrm{FV}_{\mathrm{it}}+\beta_{7} \\
\mathbf{R O A}_{\mathrm{it}}+\boldsymbol{\beta}_{8} \mathrm{FS}_{\mathrm{it}}+\beta_{9} \mathrm{TQ}_{\mathrm{it}}+\varepsilon_{\mathrm{it}}
\end{gathered}
$$

\section{Where:}

Dependent variable $=$ Dividend Policy $($ DP $)$.

$\boldsymbol{\beta}_{0}=$ denotes the fixed of the regression equation.

$\boldsymbol{\beta}_{1,2,3}$ and $4=$ MO, BO, IO and FO denotes regression coefficient of managerial ownership, block ownership, institutional ownership and foreign ownership, respectively, that are used as measures for ownership structure (OS).

$\boldsymbol{\beta}_{5}=$ denotes regression coefficient of board size (BS).

$\boldsymbol{\beta}_{6}=$ denotes regression coefficient of firm value $(\mathbf{F V})$. 
$\boldsymbol{\beta}_{7,8}$ and $\boldsymbol{\beta}_{9}=$ denotes control variables, regression coefficient of return on assets (ROA), Tobin's Q (TQ) and firm size (FS).

$\mathbf{I}_{\mathbf{t}}=$ Firm $\mathrm{i}$ in period $\mathrm{t}$.

$\mathbf{T}_{\mathbf{i}}=$ Year fixed effect.

$\varepsilon_{\mathrm{it}}=$ Standard error term.

The debt level of the company is calculated using data from the balance sheet and a ratio that is commonly employed in financial leverage. This is due to the fact that the higher the debt level, the more cash are available to pay dividends (Handriani and Robiyanto 2019). The greatest dividend yield can send a favorable signal to investors, causing their firm's value to rise. To calculate the level of financial leverage, which is the extent to which a company is financed by debt.

Managerial ownership is a percentage of share held by management, with the goal of providing a chance for a manager and allowing management to govern the company through share ownership. The role of the management will be linked with that of the firm's owner (shareholders). Control by owned managers is thought to have an impact on the firm, which in turn influences performance within the company in order to meet the company's aims of maximizing corporate value.

To meet the company's objectives, a set of targets should be established. The profitability ratio was used to examine the ability to make a profit in order to maintain and measure the company's profit. Profitability ratio also provides a measure of how deep successful management achievement is as evidenced by profit from sales and investment income, and it also demonstrates the firm's efficiency (Mappadang 2021).

Profitability was chosen as one of the control variables in this study because it can influence dividend payment decisions. Profitability has long been thought to be a reliable predictor of a company's ability to pay dividends (Gill, Biger and Tibrewala, 2010). Profitable businesses are more mature and are less likely to pursue multiple investment opportunities, which results in higher dividends.

Table (1) shows the measurements of the numerous variables and research indicators used in this research in more detail. 


\section{Table (1): Research Variables, Definitions and Measures}

\begin{tabular}{|c|c|c|c|}
\hline \multicolumn{2}{|c|}{ Variables / Type } & \multirow[b]{2}{*}{$\begin{array}{l}\text { Definition } \\
\text { The use of debt to acquire more } \\
\text { assets known as financial } \\
\text { leverage. Leverage can used to } \\
\text { increase the return on equity } \\
\text { (trading in a gain). Excessive } \\
\text { financial leverage, on the other } \\
\text { hand, increases the likelihood of } \\
\text { failure by increasing the } \\
\text { difficulty of debt repayment. } \\
\text { Firms use debt when they are } \\
\text { unable to raise enough capital to } \\
\text { meet their business requirements } \\
\text { by issuing stock. If a company } \\
\text { needs money, it will look for } \\
\text { loans, lines of credit, and other } \\
\text { types of finance. }\end{array}$} & Measure \\
\hline $\begin{array}{l}\text { Dependent } \\
\text { Variables } \\
\text { Financial } \\
\text { Leverage and } \\
\text { Dividend } \\
\text { Policy }\end{array}$ & $\begin{array}{l}\text { Financial } \\
\text { Leverage } \\
\text { (FL) }\end{array}$ & & $\begin{array}{l}\text { The ratio of total } \\
\text { debt to total assets } \\
\text { ratio is used to } \\
\text { measure Financial } \\
\text { leverage. }\end{array}$ \\
\hline & $\begin{array}{l}\text { Dividend } \\
\text { Policy (DP) }\end{array}$ & $\begin{array}{l}\text { A company's dividend policy det } \\
\text { ermines how much money it will } \\
\text { pay out to investors in the form } \\
\text { of dividends. Typically, a } \\
\text { corporation keeps a portion of its } \\
\text { profits and distributes the rest as } \\
\text { dividends. }\end{array}$ & $\begin{array}{l}\text { Dividend yield } \\
\text { measured by } \\
\text { dividend per share to } \\
\text { price per share ratio. }\end{array}$ \\
\hline \multirow[t]{2}{*}{$\begin{array}{l}\text { Independent } \\
\text { Variables } \\
\text { Ownership } \\
\text { Structure, } \\
\text { Board Size } \\
\text { and Firm } \\
\text { Value }\end{array}$} & $\begin{array}{l}\text { Managerial } \\
\text { Ownership } \\
\text { (MO) }\end{array}$ & $\begin{array}{l}\text { Ownership concentration is a key } \\
\text { internal governance technique } \\
\text { that allows owners to exert } \\
\text { control over and power over the } \\
\text { firm's management in order to } \\
\text { safeguard their interests. This } \\
\text { ownership impact gives promote } \\
\text { rs sufficient authority over the } \\
\text { company's management. }\end{array}$ & $\begin{array}{l}\text { Managerial } \\
\text { ownership measured } \\
\text { by dividing equity } \\
\text { shares owned by all } \\
\text { board directors and } \\
\text { their families to the } \\
\text { total shares } \\
\text { outstanding at the } \\
\text { end of fiscal year. }\end{array}$ \\
\hline & $\begin{array}{l}\text { Block } \\
\text { Ownership } \\
\text { (BO) }\end{array}$ & $\begin{array}{l}\text { A person or an entity that holds } \\
\text { more than } 5 \% \text { of a company's } \\
\text { outstanding shares is known as a } \\
\text { block owner. The separation of } \\
\text { ownership and control for public } \\
\text { companies may result in entirely } \\
\text { dispersed ownership, with no } \\
\text { motivation for shareholders to } \\
\text { participate in governance. Block }\end{array}$ & $\begin{array}{l}\text { The block ownership } \\
\text { structure is } \\
\text { calculated as the } \\
\text { ratio of the total } \\
\text { number of common } \\
\text { shares held by block } \\
\text { shareholders with at } \\
\text { least } 5 \% \text { of the total } \\
\text { number of common }\end{array}$ \\
\hline
\end{tabular}




\begin{tabular}{|c|c|c|}
\hline & $\begin{array}{l}\text { holders (owners of substantial } \\
\text { holdings) play a key role in long- } \\
\text { term governance, according to } \\
\text { this piece, partially through a } \\
\text { realistic threat to liquidate their } \\
\text { stakes. } \\
\text { Largeblock owners, more than } \\
\text { many small shareholders, will be } \\
\text { able to easily collaborate on } \\
\text { current issues and influence chan } \\
\text { ge in an organization. }\end{array}$ & $\begin{array}{l}\text { shares to the total } \\
\text { number of common } \\
\text { shares. }\end{array}$ \\
\hline $\begin{array}{l}\text { Institutional } \\
\text { Ownership } \\
\text { (IO) }\end{array}$ & $\begin{array}{l}\text { Mutual or pension funds, insuran } \\
\text { ce companies, investment firms, } \\
\text { private foundations, endowment, } \\
\text { and other big institutions that } \\
\text { manage funds on behalf of others } \\
\text { own a certain percentage of a } \\
\text { company's available shares. }\end{array}$ & $\begin{array}{l}\text { Institutional } \\
\text { ownership measured } \\
\text { by number of } \\
\text { outstanding shares } \\
\text { held by institutional } \\
\text { investors in a } \\
\text { company at the end } \\
\text { of fiscal year. }\end{array}$ \\
\hline $\begin{array}{l}\text { Foreign } \\
\text { Ownership } \\
\text { (FO) }\end{array}$ & $\begin{array}{l}\text { Foreign ownership or control of } \\
\text { business individuals who are not } \\
\text { citizens of a host country or by } \\
\text { corporations headquartered } \\
\text { outside of that country. Foreign } \\
\text { ownership happens when } \\
\text { multinational firms with } \\
\text { operations in multiple countries } \\
\text { make long-term investments in a } \\
\text { foreign country, typically } \\
\text { through foreign direct } \\
\text { investment or acquisition. When } \\
\text { a global corporation purchases at } \\
\text { least half of a firm, the } \\
\text { multinational company } \\
\text { transforms into a holding } \\
\text { company, and the corporation } \\
\text { acquiring the foreign investment } \\
\text { transforms into a subsidiary. }\end{array}$ & $\begin{array}{l}\text { The term foreign } \\
\text { refers to shares } \\
\text { in companies owned } \\
\text { by people from other } \\
\text { countries. A dummy } \\
\text { variable equals } 1 \text { if } \\
\text { the share of } \\
\text { enterprises held by } \\
\text { foreigners is greater } \\
\text { than } 50 \% \text { and } 0 \\
\text { otherwise, to capture } \\
\text { majority ownership. }\end{array}$ \\
\hline $\begin{array}{l}\text { Board Size } \\
\text { (BS) }\end{array}$ & $\begin{array}{l}\text { The total number of directors on } \\
\text { the board, including the CEO } \\
\text { and Chairman, is referred to as } \\
\text { board size. } \\
\text { Executive directors, and non- } \\
\text { executive directors as well as }\end{array}$ & $\begin{array}{l}\text { Board size is } \\
\text { indicated as large or } \\
\text { small based on the } \\
\text { total number of } \\
\text { directors serving on } \\
\text { the management }\end{array}$ \\
\hline
\end{tabular}




\begin{tabular}{|c|c|c|c|}
\hline & \multirow[b]{2}{*}{$\begin{array}{l}\text { Firm Value } \\
\text { (FV) }\end{array}$} & \multirow[b]{2}{*}{$\begin{array}{l}\text { outside directors } \\
\text { will be included. } \\
\text { Market value is a firm's worth } \\
\text { based on the entire market value } \\
\text { of its outstanding shares, which } \\
\text { is also known as market } \\
\text { capitalization. Because market } \\
\text { value includes profitability, } \\
\text { intangibles, and long - term } \\
\text { growth prospects, it tends to be } \\
\text { bigger than book value. }\end{array}$} & \multirow[b]{2}{*}{$\begin{array}{l}\text { board. } \\
\text { The firm's value is } \\
\text { computed as the sum } \\
\text { of the market values } \\
\text { of all existing } \\
\text { instruments, which } \\
\text { include common } \\
\text { stock, preferred } \\
\text { stock, and debt. This } \\
\text { metric is computed } \\
\text { by contrasting the } \\
\text { market value of } \\
\text { equity (capital) with } \\
\text { the adjusted value of } \\
\text { equity (equity). }\end{array}$} \\
\hline & & & \\
\hline \multirow[t]{3}{*}{$\begin{array}{l}\text { Control } \\
\text { Variables }\end{array}$} & $\begin{array}{l}\text { Financial } \\
\text { Performance } \\
\text { Return on } \\
\text { Assets (ROA) }\end{array}$ & $\begin{array}{l}\text { Return on assets compares a } \\
\text { company's profitability to its } \\
\text { total assets. ROA informs } \\
\text { managers, investors, or analysts } \\
\text { of a company's ability to } \\
\text { generate revenue from its assets. } \\
\text { ROA is calculated as a } \\
\text { percentage; the higher the ROA, } \\
\text { the better. }\end{array}$ & $\begin{array}{l}\text { ROA is calculated } \\
\text { by dividing your co } \\
\text { mpany's net income } \\
\text { by its total assets. } \\
\text { Net income is the } \\
\text { entire earnings of } \\
\text { company after } \\
\text { deducting expenses. }\end{array}$ \\
\hline & $\begin{array}{l}\text { Market } \\
\text { Performance } \\
\text { Tobin's Q } \\
\text { (TQ) }\end{array}$ & $\begin{array}{l}\text { Tobin's Q is a method of } \\
\text { determining if a particular } \\
\text { business or market is } \\
\text { undervalued or overvalued. }\end{array}$ & $\begin{array}{l}\text { Tobin's Q is the } \\
\text { market worth of a } \\
\text { corporation divided } \\
\text { by the replacement } \\
\text { cost of its assets. As } \\
\text { a result, equilibrium } \\
\text { occurs when market } \\
\text { value equals } \\
\text { replacement cost. } \\
\text { The Q Ratio, at its } \\
\text { most basic, } \\
\text { expresses the } \\
\text { relationship between } \\
\text { market valuation and } \\
\text { intrinsic worth. }\end{array}$ \\
\hline & $\begin{array}{l}\text { Firm Size } \\
\text { (FS) }\end{array}$ & The total assets of the company. & $\begin{array}{l}\text { Natural log of total } \\
\text { assets. }\end{array}$ \\
\hline
\end{tabular}




\section{$\underline{\text { Statistical Results and Data Analysis }}$}

Descriptive statistics of the variables used in the analyses to find out the nature of the data for the sample of 50 companies-year observations over the period of 2015-2020. The results of which are displayed in the table (2), that describe the results of the calculation of the minimum and maximum values, the mean, and the standard deviation of the dependent variable and all independent variables.

Table (2): Descriptive Statistics

\begin{tabular}{|c|c|c|c|c|}
\hline & Minimum & Maximum & Mean & Standard Deviation \\
\hline FL & 0.07 & 3.064 & 0.1012 & 0.106 \\
\hline DP & 8.94 & 12.971 & 9.655 & 30.628 \\
\hline MO & 2.365 & 5.698 & 7.893 & 0.369 \\
\hline BO & 3.06 & 6.984 & 20.360 & 0.456 \\
\hline IO & 5.04 & 10.369 & 18.489 & 0.568 \\
\hline FO & 3.69 & 8.235 & 15.369 & 0.236 \\
\hline BS & 5.36 & 12.36 & 18.003 & 0.387 \\
\hline FV & 47.36 & 101.23 & 25.258 & 0.169 \\
\hline ROA & 6.58 & 13.87 & 18.283 & 2.349 \\
\hline TQ & 2.35 & 5.67 & 10.369 & 5.268 \\
\hline FS & 10.36 & 19.04 & 15.025 & 6.782 \\
\hline
\end{tabular}

The average dividend yield ratio for the 50 companies for the years 20152020 is 9.655 per cent, ranging from 8.94 to 12.971 per cent. For the board of directors, the average size is 18 members, ranging from a minimum of 5.36 members to a maximum of 12.36 . The average ROA ratio is 18.283 per cent, ranging from a minimum of 6.58 per cent, and a maximum of 13.87 per cent.

A company's leverage ratio is a metric of debts that occurs as it spends. The company can evaluate its ability to carry out its liabilities with this analysis (Abrar and Arisandi 2019), particularly long duties, so that there is a risk of uncollectible debt. The level of debt is assessed through measurements to assess the relative value of the account that is significant on the measurement; in this research, the debt to asset ratio has been used.

The average of financial leverage ratio is 0.1012 per cent, ranging from a minimum of 0.07 per cent to a maximum of 3.064 per cent. The averages of share ownership by management, block holders, institutions and foreigners, are $7.89,20.36,18.48$ and 15.36 per cent, respectively. 
Firm size as a controllable variable is uses as a measure of the firm's operational activities. By examining the size of corporations, one can determine whether or not it is possible to pay dividends. Management's decisions should be visible to the public.

In general, high-level corporations have produced large profits and rarely make investments, which have an impact on dividend payment to investors (Abrar and Arisandi 2019).

High-level corporations tend to provide larger dividends since it is easier for them to obtain funds from capital market transactions and always rely on the company's internal finances, whereas low-level companies do not.

The average of firm size is 15.025 , ranging from a minimum of 10.36 to a maximum of 19.04 .

The two panel models for estimating the two multiple linear panel regression equations:

The two Pooled linear panel models all showed a high level of residuals stability in the long run, as measured by the white test for heteroscedasticity and the Chi-square test for residual normality.

In addition, the two models' independent variables and controlling variables both showed a low level of VIF, indicating no multicollinearity, and the Ramsey Reset test was used to see if there were any irrelevant variables.

The following two tables (3) and (4) summarize the two linear panel models.

The company's leverage is a ratio that measures the firm's working capital ability and the amount to which its assets are financed by debt. In comparison to its assets, the total debt is high. It will discover some way related to the utilization of own capital based on the leverage assessment. The corporation should manage leverage at an appropriate level and allocate funds to debt investment in order to increase revenue (Mappadang 2021). The leverage ratio, as an indicator of a company's financial health, is required to assist management and investors in maintaining the firm's leverage.

Table (3) shows the statistical results for the first regression model used to investigate the relationship between independent variables and financial leverage (FL). 
Table (3): Pooled Linear Panel Model for Estimating Financial Leverage (FL)

\begin{tabular}{|c|c|c|c|c|c|c|}
\hline \multirow{2}{*}{$\begin{array}{c}\text { Model } \\
\begin{array}{c}\text { Independent } \\
\text { variables }\end{array} \\
\end{array}$} & \multirow{2}{*}{\begin{tabular}{|c|}
$\begin{array}{c}\text { Pooled linear } \\
\text { Panel }\end{array}$ \\
Coefficient
\end{tabular}} & \multicolumn{2}{|c|}{$\begin{array}{c}\text { Dependent } \\
\text { variable } \\
\end{array}$} & \multirow{2}{*}{\multicolumn{2}{|c|}{\begin{tabular}{|c|}
$F L$ \\
Significance
\end{tabular}}} & \multirow{2}{*}{$\begin{array}{l}\text { VIF } \\
\text { Test }\end{array}$} \\
\hline & & t-ratio & p-value & & & \\
\hline constant & 80.65942 & 5.459 & $<0.0001$ & \multicolumn{2}{|c|}{ Significant } & \\
\hline MO & 4.32518 & 6.231 & $<0.0001$ & \multicolumn{2}{|c|}{ Significant } & 1.698 \\
\hline BO & 0.215693 & 1.189 & 0.0031 & \multicolumn{2}{|c|}{ Significant } & 1.258 \\
\hline IO & -2.25189 & -4.036 & $<0.0001$ & \multicolumn{2}{|c|}{ Significant } & 1.789 \\
\hline FO & -0.15879 & -5.495 & $<0.0001$ & \multicolumn{2}{|c|}{ Significant } & 1.697 \\
\hline BS & -2.13697 & -3.180 & 0.3211 & \multicolumn{2}{|c|}{ Insignificant } & 1.234 \\
\hline FV & 4.36984 & $\begin{array}{l}2.7 \\
41\end{array}$ & $<0.0001$ & \multicolumn{2}{|c|}{ Significant } & 1.987 \\
\hline ROA & -5.28707 & -1.398 & $<0.0001$ & \multicolumn{2}{|c|}{ Significant } & 1.235 \\
\hline FS & 0.59476 & 3.471 & $<0.0001$ & \multicolumn{2}{|c|}{ Significant } & 1.258 \\
\hline $\mathbf{T Q}$ & 2.36489 & 4.268 & 0.2341 & \multirow{2}{*}{\multicolumn{3}{|c|}{\begin{tabular}{|l} 
Insignifican \\
$60.0742 \%$
\end{tabular}}} \\
\hline \multicolumn{3}{|c|}{ Adjusted R-squared } & \multicolumn{2}{|c|}{$60.0742 \%$} & & \\
\hline \multirow{2}{*}{\multicolumn{3}{|c|}{ Ramsey RESET overall Test }} & \multicolumn{2}{|c|}{ F-test } & \multicolumn{2}{|c|}{$\mathbf{P}$ - value } \\
\hline & & & \multicolumn{2}{|c|}{27.1259} & \multicolumn{2}{|c|}{1.235698} \\
\hline \multirow{2}{*}{\multicolumn{3}{|c|}{ Overall test of Heteroscedasticity }} & \multicolumn{2}{|c|}{ Chi-square } & \multicolumn{2}{|c|}{$\mathbf{P}$ - value } \\
\hline & & & \multicolumn{2}{|c|}{65.125489} & \multicolumn{2}{|c|}{0.000004} \\
\hline \multirow{2}{*}{\multicolumn{3}{|c|}{ Normality of Residuals }} & \multirow{2}{*}{\multicolumn{2}{|c|}{$\begin{array}{c}\text { Chi-square } \\
95.125\end{array}$}} & \multicolumn{2}{|c|}{$\mathbf{P}$ - value } \\
\hline & & & & & \multicolumn{2}{|c|}{0.04072} \\
\hline
\end{tabular}

Source: Prepared by the researcher.

\section{Based on the preceding table, it is concluded that:}

- The overall Pooled model is significant with adjusted $\mathrm{R}$-squared value of $60.0742 \%$ which means that the significant independent variables and the controlling variables (return on assets and firm size) explain the change in the $\boldsymbol{F} \boldsymbol{L}$ by $60.0742 \%$.

- All the explanatory variables and the controlling variables have significant impact on financial leverage except board size and Tobin's $Q$ ratio have insignificant impact on financial leverage and removed from the regression model.

- Managerial and block holder ownership structure, firm value and firm size have a positive significant impact on the firm' financial leverage, while institutional and foreign ownership structure and profitability are 
found to have a significant negative relationship with firm' financial leverage.

- Because of the P-value $<0.0001$, a significant and positive influence was found, indicating that the higher the financial leverage, the higher the firm value, and vice versa, the lower the financial leverage and the lower the business value. This research shows that the higher the total debt to asset ratio in the capital structure, the higher the company's asset, and thus the higher the firm's value. The positive direction of the coefficient of influence is consistent with the Trade-Off theory, which claims that increasing debt would directly affect the increase in business value if the corporation is regarded to have made many investments that raise firm value through debt.

- The overall equation for forecasting the $\boldsymbol{F} \boldsymbol{L}$ is:

\section{$\mathrm{FL}_{\mathrm{it}}==80.65942+4.32518 \mathrm{MO}_{\mathrm{it}}+0.215693 \mathrm{BO}_{\mathrm{it}}-2.25189 \mathrm{IO}_{\mathrm{it}}-$ $0.15879 \mathrm{FO}_{\text {it }}+4.36984 \mathrm{FV}_{\mathrm{it}}-5.28707 \mathrm{ROA}_{\mathrm{it}}+0.59476 \mathrm{FS}_{\mathrm{it}}$}

Table (4) shows the statistical results for the first regression model used to investigate the relationship between independent variables and dividend policy (DP). 


\section{Table (4): Pooled Linear Panel Model for Estimating Dividend Policy (DP)}

\begin{tabular}{|c|c|c|c|c|c|c|}
\hline \multirow{2}{*}{$\frac{\text { Model }}{\begin{array}{c}\text { Independent } \\
\text { variables }\end{array}}$} & \multirow{2}{*}{$\begin{array}{c}\begin{array}{c}\text { Pooled linear } \\
\text { Panel }\end{array} \\
\text { Coefficient }\end{array}$} & \multicolumn{2}{|c|}{$\begin{array}{c}\text { Dependent } \\
\text { variable }\end{array}$} & \multirow{2}{*}{\multicolumn{2}{|c|}{\begin{tabular}{|c}
$D P$ \\
Significance
\end{tabular}}} & \multirow{2}{*}{ VIF Tes } \\
\hline & & t-ratio & p-value & & & \\
\hline constant & 22.5897 & 2.259 & 0.1583 & \multicolumn{2}{|c|}{ Insignificant } & \\
\hline MO & 1.45987 & 5.528 & 0.0078 & \multicolumn{2}{|c|}{ Significant } & 3.257 \\
\hline BO & -2.36985 & -6.258 & 0.3571 & \multicolumn{2}{|c|}{ Insignificant } & 3.568 \\
\hline IO & -0.12549 & -0.487 & 0.0034 & \multicolumn{2}{|c|}{ Significant } & 1.785 \\
\hline FO & 1.58236 & 2.235 & 0.0037 & \multicolumn{2}{|c|}{ Significant } & 1.048 \\
\hline$\overline{B S}$ & 3.74568 & 3.157 & 0.0017 & \multicolumn{2}{|c|}{ Significant } & 1.354 \\
\hline$\overline{\text { FV }}$ & 0.12359 & 0.487 & 0.0080 & \multicolumn{2}{|c|}{ Significant } & 1.122 \\
\hline ROA & 5.45879 & 2.368 & 0.0079 & \multicolumn{2}{|c|}{ Significant } & 1.321 \\
\hline FS & 0.58974 & 3.257 & 0.0073 & \multicolumn{2}{|c|}{ Significant } & 1.257 \\
\hline TQ & 0.87459 & 0.487 & 0.0056 & \multicolumn{2}{|c|}{ Significant } & 1.879 \\
\hline \multicolumn{3}{|c|}{ Adjusted R-squared } & \multicolumn{4}{|c|}{$72.5481 \%$} \\
\hline \multirow{2}{*}{\multicolumn{3}{|c|}{ Ramsey RESET overall Test }} & \multicolumn{2}{|c|}{ F-test } & \multicolumn{2}{|c|}{$\mathbf{P}$-value } \\
\hline & & & \multicolumn{2}{|c|}{1.225871} & \multicolumn{2}{|c|}{0.354} \\
\hline \multirow{2}{*}{\multicolumn{3}{|c|}{ Overall test of Heteroscedasticity }} & Chi-s & quare & & - value \\
\hline & & & \multicolumn{2}{|c|}{20.154870} & \multicolumn{2}{|c|}{0.002578} \\
\hline \multirow{2}{*}{\multicolumn{3}{|c|}{ Normality of Residuals }} & \multirow{2}{*}{\multicolumn{2}{|c|}{$\frac{\text { Chi-square }}{175.358}$}} & \multicolumn{2}{|c|}{$P$-value } \\
\hline & & & & & & $\overline{06000}$ \\
\hline
\end{tabular}

Source: Prepared by the researcher.

Based on the preceding table, it is concluded that:

- The overall pooled effect model is significant with adjusted R-squared value of $72.5481 \%$ which means that the significant independent variables and the controlling variables (return on assets, firm size and Tobin's Q) explain the change in the $\boldsymbol{D P}$ by $72.5481 \%$.

- All the explanatory variables and the controlling variables have significant impact on dividend policy except block holder ownership structure should be removed from the regression equation as their $\mathrm{p}$ value are 3.571 which are greater than 0.05.

- All the explanatory variables used in the second regression model have a positive significant impact on firm' dividend policy, while block 
holder ownership structure have an insignificant negative relationship with dividend policy.

- The findings indicated that the hypothesis: dividend policy has a significant impact on firm value is accepted. The direction coefficient is marked positively, indicating that any changes in dividend policy will have a significant impact on the variable firm value.

- The size of a firm has an impact on its dividend policy. When compared to small and new businesses, firm size will impact profitability and stability, as well as easier access to financial markets and lower transaction costs. Dividends paid by large corporations tend to be higher than those paid by smaller and newer enterprises. The size of the firm helps to understand the dividend payout ratio. Large firms had records of easy access to varied external funds, profitability, and stability. Investors' positive responses might boost a firm's value (Rizqia and Sumiati 2013).

- The ability of capital invested in total assets to generate profits is demonstrated by profitability, the higher the level of profitability of dividend distribution, the greater the company's ability to earn income or profit impact on dividend policy (Tamrin et al. 2018). If a company has a high level of profitability, it will earn high profits and, as a result, the amount of profit available for distribution as dividends to shareholders will be greater.

- The greater the company's profits, the greater the dividends paid to shareholders or the amount allocated to retained earnings (Sartono 2001). Profitability has an impact on dividend policy because dividends are calculated as a percentage of the company's net income. As a result, the dividend will be paid out if the company makes a profit.

- Dividend policies, according to the findings, may strengthen the profitability-firm value relationship because investors must prioritize long-term returns such as dividends. When they are optimistic about the current year's dividend performance, they can increase their investment because it increases future profitability. In this case, dividend policy may increase the value of a company and its relationship with profitability (ROA).

- A higher dividend payout becomes a sign of a higher expected return. A high dividend payout strategy demonstrates a company's ability to 
increase financial shareholder claims and improve their wealth. As the dividend ratio is increased, the firm's value creation improves. In the end, it raises the market value of the shares and the company's value. A high dividend payment strengthens the company's goodwill and reputation and is an excellent indicator of distributing wealth among shareholders and increasing firm value.

- The overall equation for forecasting the $\boldsymbol{D P}$ is:

$$
\begin{gathered}
\mathrm{DP}_{\mathrm{it}}=1.45987 \mathrm{MO}_{\mathrm{it}}-0.12549 \mathrm{IO}_{\mathrm{it}}+1.58236 \mathrm{FO}_{\mathrm{it}}+3.74568 \mathrm{BS}_{\mathrm{it}}+ \\
\mathbf{O . 1 2 3 5 9} \mathrm{FV}_{\mathrm{it}}+5.45879 \mathrm{ROA}_{\mathrm{it}}+\mathbf{0 . 5 8 9 7 4} \mathrm{FS}_{\mathrm{it}}+0.87459 \mathrm{TQ}_{\mathrm{it}}
\end{gathered}
$$

The forecasting charts of the two linear panel models are presented in figure (2).
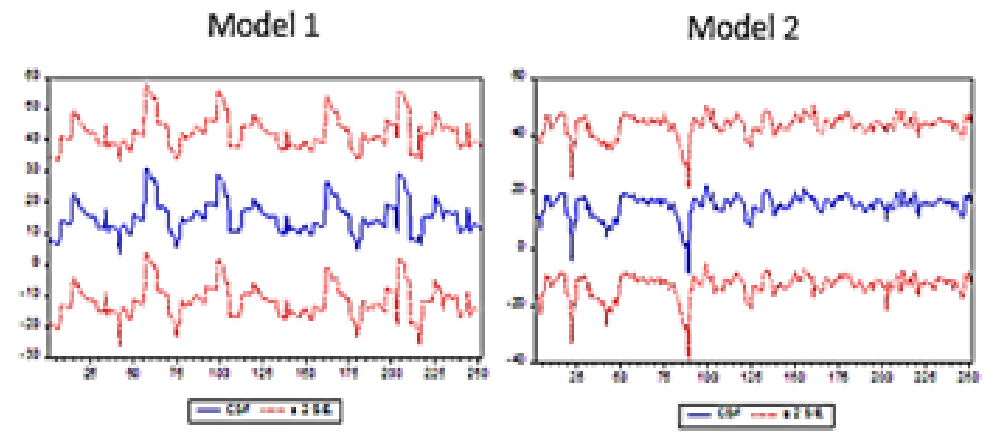

Figure (2): The Forecasting Charts of the two Linear Panel Models Source: E-views software.

The table (5) summarizes the results of the two linear panel regression models and their hypotheses. 
Table (5): Summary of the Two Linear Panel Regression Models and their Sub-Hypotheses

\begin{tabular}{|c|c|c|}
\hline \multicolumn{3}{|c|}{ Model } \\
\hline \multirow[t]{2}{*}{$\begin{array}{c}\text { Overall } \\
\text { Hypothesis }\end{array}$} & $\begin{array}{l}\text { First Hypothesis } \\
\text { Firm ownership structure, } \\
\text { board size and firm value } \\
\text { have significant positive } \\
\text { impact on financial } \\
\text { leverage. }\end{array}$ & $\begin{array}{l}\text { Second Hypothesis } \\
\text { Firm ownership structure, } \\
\text { board size and firm value } \\
\text { have significant positive } \\
\text { impact on dividend policy. }\end{array}$ \\
\hline & Ownership structure & Ownership structure has \\
\hline \multirow[t]{3}{*}{$\begin{array}{c}\text { Sub- } \\
\text { Hypothesis }\end{array}$} & $\begin{array}{l}\text { has a significant positive } \\
\text { impact on financial } \\
\text { leverage. } \\
\text { - Managerial ownership has a } \\
\text { significant positive impact on } \\
\text { financial leverage. (Accepted) } \\
\text { - Block holder ownership has a } \\
\text { significant positive impact on } \\
\text { financial leverage. (Accepted) } \\
\text { - Institutional ownership has a } \\
\text { significant positive impact on } \\
\text { financial leverage. (Rejected) } \\
\text { - Foreign ownership has a } \\
\text { significant positive impact on } \\
\text { financial leverage. (Rejected) }\end{array}$ & $\begin{array}{l}\text { a significant positive impact } \\
\text { on dividend policy. } \\
\text { - Managerial ownership has a } \\
\text { significant positive impact on } \\
\text { financial leverage. (Accepted) } \\
\text { - Block holder ownership has a } \\
\text { significant positive impact on } \\
\text { financial leverage. (Rejected) } \\
\text { - Institutional ownership has a } \\
\text { significant positive impact on } \\
\text { financial leverage. (Rejected) } \\
\text { - Foreign ownership has a } \\
\text { significant positive impact on } \\
\text { financial leverage. (Accepted) }\end{array}$ \\
\hline & $\begin{array}{c}\text { Large Board size has a } \\
\text { significant positive impact } \\
\text { on financial leverage. } \\
\text { (Rejected) }\end{array}$ & $\begin{array}{c}\text { Large Board size has a } \\
\text { significant positive impact on } \\
\text { dividend policy. } \\
\text { (Accepted) }\end{array}$ \\
\hline & $\begin{array}{l}\text { Firm value has a significant } \\
\text { positive impact on financial } \\
\text { leverage. } \\
\text { (Accepted) }\end{array}$ & $\begin{array}{l}\text { Firm value has a significant } \\
\text { positive impact on dividend } \\
\text { policy. } \\
(\text { Accepted }) \\
\end{array}$ \\
\hline
\end{tabular}

Source: Prepared by the researcher. 


\section{Conclusion}

This research using the multiple regression analysis investigates the influence of ownership structure, board size, and firm value on corporate financial leverage and dividend policy.

Towards that end we examined a sample of 50 listed Egyptian firms during the period 2015-2020. The results confirm the relevance and significance of managerial ownership and board size and firm value in corporate financial decision regarding financial leverage and dividend policy.

Institutional ownership negatively affects both corporate leverage and dividend yield. This means that the company's management does not consider the amount of shares owned by the institution when determining dividend policy. This is possible because not all institutional investors seek to profit solely from dividends. If the investor does not want dividends, the company's profit will be better for the company's expansion, which will improve the company's performance and eventually increase the stock price, which will increase the institutional investor's profit.

Managerial ownership positively affects both corporate leverage and dividend yield. This result suggests that increased managerial ownership will lead to a increase in the distribution of dividends.

Profitability and Tobin's Q both have a positive impact on dividend policy. This means that the amount of the dividend will be determined by the size of the company's profits.

Firm size found to have a positive effect on both corporate leverage and dividend yield.

The results also demonstrate that the relevance of firm value on the level of financial leverage and in deciding whether to increase or decrease the amount of dividends distributed. When the dividend policy is announced, the company has achieved higher expected returns and is highly regarded in the capital markets. In addition, it reduces information asymmetry, increases corporate profitability, and increases corporate value. 


\section{References}

Abdelsalam, O., El-Masry, A., and Elsegini, S. (2008). Board composition, ownership structure and dividend policies in an emerging market: Further evidence from CASE 50. Managerial Finance, 5 (3), 14-38.

Abdullah, N.M.H., Ahmad, Z. and Roslan, S. (2012). Capital structure effect on firms' performance: Focusing on consumers and Industrials Sectors on Malaysian Firms. International Review of Business Research Papers, 8 (5), 137-155.

Abel, E. E and Okafor, F. O. (2010). Local corporate ownership and capital structure decisions in Nigeria: A developing country perspective. Corporate Governance, 10(3), 249-260.

Abobakr, M. G., and Elgiziry, K. (2016). The effect of board characteristics and ownership structure on the corporate financial leverage. Accounting and Finance Research, 5(1), 1-14.

Abor, J. (2007). Corporate governance and financing decisions of Ghanaian listed firms, corporate governance. International Journal of Business in Society, 7(1), 83-92.

Abrar, B., Ghazyla, R., and Arisandi, D. (2019). Analysis the impact of profitability, liquidity, leverage and company size on dividend policy. Indonesian Management and Accounting Research, 16(2), 1-16.

Adams, R., and Mehran, H. (2002). Is corporate governance different for bank holding companies?. Federal Reserve Bank of New York Economic Policy Review, 2(1), 123-42.

Ajanthan, A. (2013). The relationship between dividend payout and firm profitability: A study of listed hotels and restaurant companies in Sri Lanka. International Journal of Scientific and Research Publications, 3(5), $1-6$.

Alenazi, H., and Barbour, B. (2019). The relationship between dividend policy and firm value within Qatari banks. QScience Connect, 3(5), 1-22.

Al-Gharaibeh, M., Al-Zurigat, Z. and Al-Harasheh, K. (2013). The effect of ownership structure on dividends policy in Jordanian companies. Interdisciplinary Journal of Contemporary Research in Business, 4(9), 769-796. 
Al-Sa'eed, M. T. A. A. (2018). The impact of ownership structure and dividends on firm's performance: evidence from manufacturing companies listed on the Amman stock exchange. Australasian Accounting, Business and Finance Journal, 12(3), 107-126.

Anderson R., Mansi, S. and Reeb, D. (2004). Board characteristics, accounting report integrity and the cost of debt. Journal of Accounting and Economics, 37, 315-342.

Arbor, G. (2008). Agency theoretic determinants of debt levels: evidence from Ghana. Review of Accounting and Finance, 7(2), 183-192. http://dx.doi.org/10.1108/14757700810874146

Arifin, S., and Asyik, F. (2015). Pengaruh Profitabilitas, Likuiditas, Growth Potensial, Dan Kepemilikan Manajerial Terhadap Kebijakan Dividen. 4(2), 1-16.

Arshad H. and Safdar A. B. (2009). Impact of ownership structure and corporate governance on capital structure of Pakistani listed companies. International Journal of Business and Management, 4(2), 50-57.

Asiri, F. M., Sutrisno, T., and Andayani, W. (2018). The influence of ownership structure and company characteristics of dividend policy with sales growth as moderation variable. Asia Journal of Contemporary Business, Economics and Law, 15(5), 252-260.

Bansal, C.L. (2005). Corporate governance - law practice and procedures with case studies. New Delhi: Taxmann Allied Service (P) Ltd. 2-11, 163-234.

Berger, A., and Bonaccorsidipatti, E. (2006). Capital structure and firm performance: A new approach to testing agency theory and an application to the banking industry. Journal of Banking \& Finance, 30(4), 1065-1102.

Berger, P. G., Ofek, E., and Yermack, D. L. (1997). Managerial entrenchment and capital structure decisions. Journal of Finance, 52(4), 1411-1438.

Brailsford, B. R. (2002). On the relation between ownership structure and capital structure. Journal of Accounting and Finance. 42, 1-26

Brealey, R. A., Myers, S. C., Allen, F., and Mohanty, P. (2012). Principles of Corporate Finance. Tata McGraw-Hill Education.

Djumahir. (2011). Pengaruh Biaya Agensi, Tahap Daur Hidup Perusahaan, dan Regulasi terhadap Kebijakan Dividen pada. 
Embara, C., Wiagustini, N., and Badjra, B. (2012). Variabel - Variabel yang Berpengaruh terhadap Kebijakan Dividen serta Harga Saham Pada Perusahaan Manufaktur di Bursa Efek Indonesia .Jurnal Manajemen, Strategi Bisnis, dan Kewirausahaan, 6(2), 119-127.

Farinha, J. (2003). Dividend policy, corporate governance and the managerial entrenchment hypothesis: an empirical analysis, Journal of Business Finance and Accounting, 30(9-10), 306-686.

Faulkender, M., Milbourn, T., and Thakor, A. (2006). Capital structure and dividend policy: two sides of the same coin. Washington University in St. Louis, working paper.

Fosberg, R.H. (2004). Agency problem and debt financing: leadership structure effects. Corporate Governance, 4(1), 31- 38. http://dx.doi.org/10.1108/14720700410521943

Gill, A., Biger, N and Tibrewala, R. (2010). Determinants of Dividend Payout Ratios: Evidence from United States. The Open Business Journal, 3, 8-14.

Gitman, L.J. and Zutter, C.J. (2012). Principles of Managerial Finance, $13^{\text {th }}$ Edition, Pearson Education, Inc, ISBN: 978-0-27-375428-2.

Gugler, K. (2003). Corporate governance, dividend payout policy and the interrelation between dividends, $\mathrm{R} \& \mathrm{D}$, and capital investment, Journal of Banking and Finance, 27(7), 1297-321.

Handriani, E., and Robiyanto, R. (2019). Institutional ownership, independent board, the board size, and firm performance: Evidence from Indonesia. Contaduría y administración, 64(3), 1-16.

Hommei, Maikel. (2011). Dividend policy and ownership structure in the Netherlands. Master Thesis Financial Management. Tilburg University.

Hussainey, K., and Aljifri, k. (2012). Corporate governance mechanisms and capital structure in UAE. Journal of Applied Accounting Research, 13(2), 145-160. http://dx.doi.org/10.1108/09675421211254849

Ibrahim, U. A., and Isiaka, A. (2020). Effect of financial leverage on firm value: Evidence from selected firms quoted on the Nigerian stock exchange. European Journal of Business and Management, 12(3), 124135. 
Jensen, M. and W. Meckling, (1976). Theory of the firm: Managerial behavior, agency costs and ownership structure, Journal of Financial Economics, 3(4), 305-360.

Jensen, M. C. (1986). Agency costs of free cash flow, corporate finance, and takeovers. The American Economic Review, 76(2), 323-329.

Jensen, M. C., and Meckling, W. H. (1976). Theory of the firm: Managerial behavior, agency costs and ownership structure. Journal of Financial Economics, 3(4), 305-360.

La Porta, R., Lopez-de-Silane, F., Shleifer, A., and Vishny, R. W. (2000). Agency problems and dividend policies around the world. The Journal of Finance, 55(1), 1-33.

Mappadang, A. (2021). Managerial ownership, leverage, profitability, corporate value: An interactive effect in Indonesia stock exchange. Widyakala: Journal of Pembangunan Jaya University, 8(2), 5460 .

Moloi, T., Nharo, T., and Hlobo, M. (2021). The relationship between board characteristics and dividend payment policies: The JSE Top 40 listed companies cases. Journal of Academic Finance, 12(1), 30-52.

Mubaraq, M., Rahayu, S. M., Saifi, M., and Darmawan, A. (2021). The moderating effect of corporate governance on the relationship between dividend policy, capital structure, and firm value: Evidence from Indonesian manufacturer companies. European Journal of Molecular \& Clinical Medicine, 8(1), 880-889.

Nuhu, E. (2014). Revisiting the determinants of dividend payout ratios in Ghana. International Journal of Business and Social Science, 5(8), 230238.

Purbawangsa, I., and Rahyuda, H. (2020). The effect of ownership structure, dividend policy, composition of the board of directors on financial performance and share return. Accounting, 8(1), 1-8.

Ramirez, F. S., and Ferrer, R. C. (2021). The mediating role of dividend policy on the impact of capital structure and corporate governance mechanisms on firm value among publicly listed companies in the Philippines. DLSU Business \& Economics Review, 31(1), 95-111. 
Rizqia, D. A., and Sumiati, S. A. (2013). Effect of managerial ownership, financial leverage, profitability, firm size, and investment opportunity on dividend policy and firm value. Research Journal of Finance and Accounting, 4(11), 120-130.

Said, H. B. (2013). Impact of ownership structure on debt equity ratio: A static and a dynamic analytical framework .International Business Research, 6(6), 162-180. DOI: 10.5539/ibr.v6n6p162.

Saifi et al. (2015). The effect of corporate governance and investment opportunity set on capital structure, dividend policy, and firm performance (A study on go-public manufacturing companies in Indonesia stock exchange). International Journal of Management and Administrative Sciences, 3(2), 53.

Sartono, A. (2001). Financial management theory and application. Yogyakarta: BPFE.

Shah, A. Z., Ullah, W., and Hasnain, B. (2011). Impact of ownership structure on dividend policy of firm. In 2010 International Conference on EBusiness, Management and Economics IPEDR, (3), 22-26.

Shahid, M. S., Gul, F., and Rizwan, M. (2016). Ownership structure, board size, board composition and dividend policy: New evidence from two emerging markets. IBT Journal of Business Studies (JBS), 2(2), 25-36.

Silva, C.D., Andre L., and Leal, R.P.C. (2004). Corporate governance and value in Brazil. Frontiers in Finance and Economics, 1-16.

Soewarno, N., Arifin, S. Y., and Tjahjadi, B. (2017). The mediating effect of leverage and dividend policy on the influence of corporate governance towards firm value. In SHS Web of Conferences, 34, 04002. EDP Sciences.

Subramaniam, R., Devi, S. S., and Marimuthu, M. (2011). Investment opportunity set and dividend policy in Malaysia. African Journal of Business Management, 5(24), 128-143.

Tahir, H., Masri, R., and Rahman, M. (2020). Corporate board attributes and dividend pay-out policy: Mediating role of financial leverage. The Journal of Asian Finance, Economics, and Business, 7(1), 167-181.

Tamrin, M., Mus, H. R., and Arfah, A. (2018). Effect of profitability and dividend policy on corporate governance and firm value: Evidence from the Indonesian manufacturing sectors, 19(10), 66-74. 
Thanatawee, Y. (2013). Ownership structure and dividend policy: Evidence from Thailand. International Journal of Economics and Finance, 5(1), 121-132.

Laghari, A. (2017). The impact of the operating leverage and financial leverage on the firm's value: Empirical evidence from Pakistan. Available from: https://www.ssrn.com/abstract=3421416.

Ullah, H., Fida, A. and Khan, S. (2012). The impact of ownership structure on dividend policy evidence from emerging markets KSE-100 index Pakistan. International Journal of Business and Social Science, 3(9), 298-307.

Uwuigbe, O. R. (2013). Corporate governance and share price: Evidence from listed firms in Nigeria. African Research Review, 7(2), 129-143.

Wen, Y., Rwegasira, K. and Bilderbeek, J. (2002). Corporate governance and capital structure decisions of Chinese listed firms. Corporate Governance: An International Review, 10 (2), 75-83.

Weston, J. F. and Copeland, T. E. (2002). Manajemen Keuangan. Jakarta: Binarupa Aksara. 